Vol. 13 (2004): 348-362.

\title{
Effects of winter feeding strategies with alternative feeds on the performance of mature suckler cows and their progeny
}

\author{
Merja Manninen, Kirsi Saarijärvi \\ MTT Agrifood Research Finland, North Savo Research Station, FI-71750 Maaninka, Finland, \\ e-mail: merja.manninen@mtt.fi
}

Harri Huhta

MTT Agrifood Research Finland, Environmental Research, Ecological Production, FI-50100 Mikkeli, Finland

Lauri Jauhiainen

MTT Agrifood Research Finland, Research Services, FI-31600 Jokioinen, Finland

Pentti Aspila

MTT Agrifood Research Finland, FI-31600 Jokioinen, Finland

\begin{abstract}
The present study evaluated the effects of feeding strategies with alternative feeds on the performance of mature suckler cows and their progeny during indoor feeding and subsequent grazing. In both experiments, a $2 \times 2$ factorially arranged design consisted of two feeding strategies (Step-up, S; Flat-rate, F) and two diets (Control, C; Alternative, A). The aim of Strategy F was to offer the cows the same amount of energy as offered on Strategy S, but at a constant daily level. In Experiment 1, cows on Diet C were offered grass silage and straw and on Diet A grass silage and a flour-mill industry by-product. On Strategy S, feeding was stepped with barley $\left(0,1.5\right.$ and $\left.3.5 \mathrm{~kg} \mathrm{~d}^{-1}\right)$. On Strategy F, barley was offered $1.43 \mathrm{~kg}$ per head daily. In Experiment 2, cows were offered either grass silage (C) or whole-crop barley silage (A) as a sole feed. Strategy S was carried out by offering 68, 95 and 119 MJ metabolizable energy (ME) per cow daily. On Strategy F, roughage was given daily 97 MJ ME. In both experiments, there were no significant differences between treatments in the cow live weight, body condition score, calf pre-weaning live weight gain and cow reproduction. Strategy F can be practised in the nutrition of mature suckler cows in marginal circumstances. Flour-mill industry by-product can partly replace grass silage and straw in the winter diet. Wholecrop barley silage can be offered as a sole feed to suckler cows with good body condition score in autumn.
\end{abstract}

Key words: beef, feeding, by-products, milk, whole-crop silage, body condition 
Vol. 13 (2004): 348-362.

\section{Introduction}

With dairy cows, the term flat-rate feeding strategy refers to a similar daily allocation of concentrates throughout lactation (Poole 1987). With suckler cows, presumably the traditional feeding strategy for the herd during the indoor feeding period is an allotment of the feeds taking into account the estimated calving date of the cow, in other words, the step-up feeding strategy. However, in many cases the estimated calving date might be unknown due to the absence of a pregnancy diagnosis. Step-up feeding is not difficult for a single cow but even the best managed beef herds usually calve over an eight to ten weeks period (Broadbent 1984). Therefore, more simple feeding strategies are needed. Although the flat-rate feeding system for mature beef cows, involving the entire diet, is successfully practised on some farms, no scientific study on this subject is available. For dairy cows, the flat-rate feeding system for concentrates has been widely reported (Poole 1987, Andries et al. 1988) but the results reported for dairy cows cannot be utilized for the suckler cows.

Indoor feeding of beef cows is usually based on inexpensive, low-energy feeds such as straw, treated straw (Mann et al. 1988, Fike et al. 1995, Manninen et al. 2000) or straw with protein or energy supplements (Alawa et al. 1986, Alawa et al. 1987, Alawa et al. 1988, Beck et al. 1992). Good quality grass silage is not used for beef cows ad libitum due to its high energy content, especially for cows in good body condition score pre-calving. Sometimes the availability of straw may be limited due to the weather conditions in the autumn or the geographical situation of the farm, or the available straw has to be reserved for litter. Results reported concerning the effects of flour-mill industry byproducts or other alternative feeds such as wholecrop silages are common in the feeding of dairy cows (Hameleers 1998, Sutton et al. 2001) and beef cattle (O'Kiely and Moloney 1995, Komprda and Dolezal 1996, Moloney and O'Kiely 1997, Varhegyi et al. 2000), but not in the feeding of suckler cows. Therefore, beef cow producers need more information about alternative feeds suitable for indoor feeding. In addition, the utilization of flour-mill industry by-products for cattle, when possible, is important for the feed industry.

The following two experiments were undertaken to evaluate the effects of flat-rate vs. step-up feeding strategies with alternative feeds on the performance of mature suckler cows during a long indoor feeding period and subsequent grazing. The aim was to study if flat-rate feeding strategy instead of step-up feeding can be successfully carried out during the indoor feeding period, and if grass silage and straw can be replaced with other feeds. In Experiment 1 (Exp1), the influence of feeding strategy on the performance of Aberdeen Angus $\times$ Ayrshire (AbAy) and Charolais $\times$ Ayrshire (ChAy) cows was studied using either straw or a flour-mill industry by-product (BP) in the winter diet. In Experiment 2 (Exp2), the effects of feeding strategy on the performance of the Hereford (Hf) cows were studied using either grass silage (GS) or whole-crop barley silage (WCBS) as a sole winter feed. The effects of treatments on cow feed intake, diet digestibility (Exp2), live weight (LW), body condition score (BCS), milk production (Exp1), incidence of dystocia and calf performances are discussed in this paper.

\section{Material and methods}

\section{Animals and experimental design}

Twenty-four AbAy cows with an initial LW of 537 $\mathrm{kg}$ and $32 \mathrm{ChAy}$ cows with an initial LW of $589 \mathrm{~kg}$ on 1 November, and $56 \mathrm{Hf}$ cows with initial LW of $692 \mathrm{~kg}$ on 1 December were selected for Exp1 and Exp2, respectively. All animals were mature and pregnant to a Limousin (Li, Exp1) and Hf (Exp2) bull. In both experiments, four treatments in a $2 \times 2$ factorially arranged design consisted of two feeding strategies (Step-up, S; Flat-rate, F) and two diets (Control, C; Alternative, A). Initial LW, predicted calving date (gestational age assessed by ultrasonographic foetometry) and breed (Exp1) were used to allocate animals to groups and after 
that the treatments were randomly assigned to groups.

The animals were group-fed, once daily in the morning. Seven animals were kept per pen and there were two pens per treatment. In Exp1, each pen contained three AbAy cows and four ChAy cows. Exp1 and Exp2 consisted of two main periods, an indoor feeding period averaging 212 and 177 days and a grazing period averaging 74 and 102 days, respectively. On Strategies S, the indoor feeding comprised three periods which were from the start to 60 days pre-calving (95 and 58 days), the last 60 days pre-calving (64 and 57 days) and from calving to grazing (52 and 62 days) in Exp1 and Exp2, respectively. In Exp1, the indoor feeding ended 9 days before grazing commenced due to a shortage of one of the experimental feeds. For this interim period feed consumption data is not available. Grazing commenced on 1 June and on 26 May and the experiments ended on 14 August and 5 September in Exp1 and Exp2, respectively. The animal housing facilities were documented by Manninen et al. (1998). The experiments were carried out at Tohmajärvi Research Station located in eastern Finland. The average vegetation period is 155 days and grazing period 100-120 days.

\section{Feeds and indoor feeding}

In both experiments, wilted meadow fescue-timothy-red clover (Festuca pratensis - Phleum pratense - Trifólium praténse) GS was made using a mower conditioner and a precision chopper. Whole-crop barley silage was made at the dough stage using a double chopper. Silages were ensiled in bunker silos and clamps using a formic acid based additive, applied at $51 \mathrm{t}^{-1}$. Pelletted and crushed BP included $\left(\mathrm{g} \mathrm{kg}^{-1}\right)$ oat hull (850), dried grass meal (80), wheat molasses (50) and calcium lignosulfonate (20). Wheat molasses is hydrolysed wheat-starch including water-soluble carbohydrates approximately $60 \%$ of the dry matter (DM). Barley and barley straw were harvested conventionally.

The amount of feed offered and refused was recorded daily for each group. In Exp1, animals on
Diet $\mathrm{C}$ were given GS and straw in the proportions 0.55 and 0.45 and on Diet A GS and BP in the proportions 0.30 and 0.70 on a DM basis, respectively. On Strategy S, milled barley was offered individually with three steps which were none from the onset of the experiment to 60 days pre-calving, 1.5 $\mathrm{kg} \mathrm{d}^{-1}$ for the last 60 days pre-calving and $3.5 \mathrm{~kg}$ $\mathrm{d}^{-1}$ post-calving. On Strategy F, $1.43 \mathrm{~kg} \mathrm{~d}^{-1}$ milled barley was offered per animal during the entire indoor feeding. In Exp2, the animals were offered either GS (Diet C) or WCBS (Diet A). The energy content of the GS and WCBS was evaluated prior to the experiment by measuring in vitro organic matter (OM) digestibility. Subsequently, the measured energy value of $11.1 \mathrm{MJ}$ metabolizable energy (ME) $\mathrm{kg}^{-1} \mathrm{DM}$ was used both for GS and WCBS when the diets were formulated. Strategy $S$ involved three steps which were from the onset to 60 days pre-calving, the last 60 days pre-calving and post-calving when 68, 95 and 119 MJ ME per animal were offered, respectively. On Strategy F, roughage was given at a constant daily level of 97 MJ ME d ${ }^{-1}$ during the indoor period. In both experiments, the aim of Strategy $F$ was to offer the cows an equal amount of energy during the entire indoor feeding period as that offered on Strategy $S$ but at a constant daily level. On Strategy S feed was offered according to Finnish recommendations which are based on those for dry dairy cows (Salo et al. 1982, Tuori et al. 1996). During indoor feeding cows received daily $100 \mathrm{~g}$ of a mineral mixture rich in phosphorus (Fosfori Hertta-Minera Muro: Ca 105, P 116, Na 70, Mg $75 \mathrm{~g} \mathrm{~kg}^{-1}$ ), salt lick and water. A vitamin mixture (Exp1: Karjan Teho-Vitan: A $2000000 \mathrm{IU} \mathrm{kg}^{-1}, \mathrm{D}_{3} 200000 \mathrm{IU}$ $\mathrm{kg}^{-1}$, E DL- $\alpha$-tocopheryl $1800 \mathrm{mg} \mathrm{kg}^{-1}$, Se $10 \mathrm{mg}$ $\mathrm{kg}^{-1}$ and Exp2: Xylitol ADE-Vita: A 2000000 IU $\mathrm{kg}^{-1}, \mathrm{D}_{3} 400000 \mathrm{IU} \mathrm{kg}^{-1}$, E DL- $\alpha$-tocopheryl acetate $1000 \mathrm{mg} \mathrm{kg}^{-1}$, E DL- $\alpha$-tocopheryl $900 \mathrm{mg} \mathrm{kg}^{-1}$, Se $10 \mathrm{mg} \mathrm{kg}^{-1}$ ) was given at $200 \mathrm{~g}$ per animal weekly.

\section{Sampling and analyses}

During the indoor period, roughage feed samples for chemical analyses were taken at every feeding 
Vol. 13 (2004): 348-362.

and pooled over a four-week period. Barley and BP samples were pooled over an eight-week period. In Exp2, whole tract apparent OM, neutral detergent fibre (NDF), nitrogen (N) and starch digestibility coefficients were estimated using indigestible NDF as an internal marker (Lippke et al. 1986). Spot faecal samples were collected from each cow once per day on three consecutive days, twice (17-19 January and 15-17 March) before the calving period. The samples were pooled on the pen basis, thoroughly mixed, subsampled and stored at $-20^{\circ} \mathrm{C}$. During the faecal collection days, extra feed samples were collected daily.

Feed DM content was determined by oven drying at $105^{\circ} \mathrm{C}$ for 16 hours. Silage DM was corrected for volatile losses according to Huida et al. (1986). Feeds and faecal samples were analysed for ash (AOAC 1990), for total N by the Dumas method using a Leco FP 428 nitrogen analyser (Leco Corp., St Joseph, USA) and for NDF according to Van Soest et al. (1991). Starch was measured according to McCleary et al. (1994) from WCBS and faecal samples collected during the faecal collection days. The in vitro OM digestibility of the GS, WCBS and straw was estimated according to Friedel (1990). Fresh silage samples were analysed for $\mathrm{pH}$, water-soluble carbohydrates by the method of Somogyi (1945), lactic acid (Haacker et al. 1983), volatile fatty acids (Exp1: Huida 1973, Exp2: Huhtanen et al. 1998), ammonia N (McCullough 1967), ethanol with an enzymatic kit (Cat No. 981680, KONE Instruments Corporation, Espoo, Finland) and soluble $\mathrm{N}$ by the Kjeldahl method using $\mathrm{Cu}$ as a digestion catalyst (AOAC 1990).

The ME value of the barley was calculated according to MAFF $(1975,1984)$ using the determined chemical composition and average digestibility coefficients reported by Tuori et al. (2000). The ME value of the BP was calculated using the energy table values for each component (Tuori et al. 2000). The ME values for the silages were calculated assuming a ME content of $16 \mathrm{MJ}$ per $\mathrm{kg}$ digestible OM for GS (MAFF 1975) and 15.5 MJ for WCBS (Tuori et al. 2000). The content of digestible OM in DM (D value) was based either on in vitro (Exp1 and Exp2) or in vivo (Exp2) meas- urement of digestibility. Amino acids absorbed in the small intestine (AAT) were calculated according to Tuori et al. (2000).

\section{Live weight, condition scoring and dystocia}

The cows were weighed at the beginning of the experiment, 1-7 days pre partum, at the onset of grazing and at the end of the experiment. In Exp1, the cows were weighed 9 days prior to the onset of grazing and this weight was used as the LW at the onset of grazing. The cows were condition-scored (Lowman et al. 1976) when weighed. In Exp1, two cows (CS and AS) were removed from the experiment after calf deaths on 25 April and on 8 July. In Exp2, one cow (CS) was slaughtered after uterine torsion and two cows (CS and AS) did not nurse their calves. Three cows (AF) had premature deliveries. All those cows were omitted from the LW and BCS results.

Calves were weighed immediately after birth and at 50 days of age, at the onset of grazing and at the end of the experiment. In Exp1, data from stillborn twins were omitted. Two male calves (CS) have only birth weight (BW) and one male calf (AS) has BW and LW at 50 days of age. In Exp2, one female calf (CS) died at the age of three weeks and one female calf (AS) has only BW. The incidence of calving difficulties was recorded using the following classification scale which was easy calving with no assistance (1), calving with slight assistance (2), difficult calving (3) and very difficult calving requiring veterinarian assistance or caesarean section (4).

\section{Milk production, grazing and fertility}

Milk production and milk composition was measured on 14, 28, 42, 56, 70, 84, 98 and 112 days of lactation in Exp1 for six cows from each treatment using the machine-milking technique earlier described by Manninen and Taponen (2004). The cows were selected on a calving date and breed 
basis per treatment and per pen, taking into account the sex of the calf and the suitability of the cow for machine-milking.

In Exp1 and Exp2, cows were divided into two mating groups (Group I and Group II) for the grazing period and two $\mathrm{Hf}$ bulls ran with the cows from 5 June to 24 August and from 25 May to $28 \mathrm{Au}-$ gust, respectively. In Exp1 and Exp2, the rotationally grazed pastures consisted of meadow fescuetimothy swards, with an area of 26.7 and 37.1 ha, respectively. The pasture soil type was sandy soil. Fertilisation rate was 170 and $190 \mathrm{~kg} \mathrm{~N}^{-1}$ in Exp1 and Exp2, respectively. The pastures were topped when necessary. In Exp2, pre- and postgrazing sward height $(\mathrm{SH})$ was measured with a sward stick for each rotation. The pre-grazing pasture mass was measured and grass samples were analysed for D value, ash and crude protein $(\mathrm{CP})$ content. Cows had free access to water and a magnesium-rich mineral mixture (Viher Hertta-Minera Muro: Ca 160, P 64, Na 90, Mg $80 \mathrm{~g} \mathrm{~kg}^{-1}$ ). Ultrasonographic examinations were performed in Exp1 on 24 August and 4 October and in Exp2 on 10 August and 4 October for assessing the status of pregnancy and gestational age. The ultrasound examinations and measurement of gestational age were as described by Manninen and Taponen (2004).

\section{Statistical analysis}

The intake data and in vivo digestibility coefficients were evaluated by group and analysed using one-way analysis of variance. The rest of the variables were recorded individually. The betweenpens variation was used as an error term when treatments were compared, because treatments were allocated to animals penned together in groups. Therefore the response variable, y, was analysed by the following statistical model:

$\mathrm{y}_{\mathrm{ijk}}=\mu+$ treatment $_{\mathrm{i}}+$ pen $_{\mathrm{j}}\left(\right.$ treatment $\left._{\mathrm{i}}\right)+$ breed $_{\mathrm{k}}$

+ treatment $\times$ breed $_{i \mathrm{k}}+$ pen $_{\mathrm{j}} \times$ breed $_{\mathrm{k}}+\mathrm{e}_{\mathrm{ijk}}$ where treatment ${ }_{i}$, breed $d_{k}$ and treatment $\times$ breed $_{i k}$ are, respectively, effects due to the ith treatment, $\mathrm{kth}$ breed and their interaction; pen $_{\mathrm{j}}$ (treatment $_{\mathrm{i}}$ ) is the error term for treatment effect; pen $_{j} \times$ breed $_{k}$ is the error term for breed; and $\mathrm{e}_{\mathrm{ijk}}$ is the betweenanimal variation. Breed $_{\mathrm{k}}$, treatment $\times$ breed $_{\mathrm{ik}}$ and pen $_{\mathrm{j}} \times$ breed $_{\mathrm{k}}$ effects were not included in the analysis of data from Exp2 because all the animals of that experiment were the same breed. Both experiments had 4 treatments ( 2 diets and 2 feeding strategies). In the analysis of calf data, the statistical model used contains birth date and sex as a regression covariant. The regression coefficient of birth date was assumed to be equal in all treatment groups. The effect of sex, however, seems to vary from treatment to treatment. Therefore, a sex-bytreatment interaction effect was included in the model. The assumptions of the models were checked by graphical methods which were scatter diagrams for constancy of error variance and box plots for normality of errors. The statistical analyses were performed by SAS (1999) software and the GLM procedure.

\section{Results}

\section{Feed value and feed intake}

The mean chemical composition of the experimental feeds is given in Table 1 and the in vivo apparent digestibility coefficients (Exp2) in Table 2. In Exp1, the GS had a high in vitro D value of $708 \mathrm{~g}$ $\mathrm{kg}^{-1} \mathrm{DM}$ but contained on average $3.9 \mathrm{~g} \mathrm{~kg}^{-1} \mathrm{DM}$ of butyric acid. The CP content of the BP was $48 \mathrm{~g}$ higher than that of the straw, mostly due to the proportion of dried grass meal in the mixture. However, the ME and AAT values were similar for both straw and BP and thus the feeds were comparable. In Exp1, the cows on Diet $\mathrm{C}$ did not consume all the straw offered but, despite this, the DM intake was on average $0.31 \mathrm{~kg}$ higher $(\mathrm{P}<0.05)$ on Diet $\mathrm{C}$ than on Diet A (Table 3). The ME, NDF and AAT intake was 17.7 MJ, $899 \mathrm{~g}$ and $125 \mathrm{~g}$ higher $(\mathrm{P}<0.001)$ on Diet $\mathrm{C}$ than on Diet A, mainly due to the higher DM intake and the higher proportion of GS on Diet C. In Exp2, cows on Diet C received 1.4 and 11.7 MJ ME more than on Diet A evaluated by the in vitro $(\mathrm{P}<0.01)$ and in vivo method $(\mathrm{P}<$ 
Vol. 13 (2004): 348-362.

$0.001)$, respectively. The digestibility coefficients of the WCBS for OM, NDF and CP were significantly lower than those for the GS $(\mathrm{P}<0.01,0.68$ vs. $0.76 ; \mathrm{P}<0.001,0.57$ vs. $0.74 ; \mathrm{P}<0.001,0.59$ vs. 0.69).

\section{Live weight, body condition score and dystocial cases of cows}

In both experiments treatments had only minor effects on cow LW and BCS (Table 4) and a very low incidence of calving problems were observed. In Exp1, the LW gain (LWG) was similar for all treatments indoors and on pasture averaging -15 and $60 \mathrm{~kg}$, respectively. A slight effect of treatment on the BCS was found at the onset of grazing since cows on Diet $C$ had on average 0.37 unit higher ( $P$ $=0.06) \mathrm{BCS}$ than those on Diet A. On pasture the $\mathrm{BCS}$ of the cows fed Diet A increased while the cows fed Diet $\mathrm{C}$ had a slightly negative change of BCS $(\mathrm{P}<0.01,0.32$ vs. -0.04$)$. Two calvings (Diets $\mathrm{CF}$ and $\mathrm{AS}$ ) were classified as difficult with the value 3 , eight calvings needed slight assistance and 46 were easy.

In Exp2, the LWG was also similar for all treatments indoors and on pasture averaging -12 and $78 \mathrm{~kg}$, respectively. The treatments had no effect on the cow BCS averaging 3.35, 3.01, 3.15 and 3.35 at the onset of the experiment, at calving, before and after grazing, respectively. One calving was classified with the value 4 due to uterine torsion, two calvings needed slight assistance and the rest were easy.

\section{Live weight of calves}

In Exp1, the average calf birth date was 10 April (Table 5). An interaction $(\mathrm{P}<0.05)$ between the

Table 1. Mean chemical composition and feed value of feeds.

\begin{tabular}{|c|c|c|c|c|c|c|}
\hline & \multicolumn{4}{|c|}{ Experiment 1} & \multicolumn{2}{|c|}{ Experiment 2} \\
\hline & Barley & Grass silage & Barley straw & $\begin{array}{l}\text { Flour-mill } \\
\text { by-product }\end{array}$ & Grass silage & $\begin{array}{l}\text { Whole-crop } \\
\text { barley silage }\end{array}$ \\
\hline Number of samples & 5 & 11 & 8 & 4 & 8 & 9 \\
\hline \multicolumn{7}{|l|}{ Chemical composition } \\
\hline Dry matter (DM), $\mathrm{g} \mathrm{kg}^{-1}$ & 872 & 265 & 876 & 883 & 301 & 335 \\
\hline \multicolumn{7}{|l|}{ In the DM, $\mathrm{g} \mathrm{kg}^{-1}$} \\
\hline Ash & 23 & 66 & 50 & 57 & 70 & 47 \\
\hline Crude protein & 122 & 116 & 35 & 83 & 148 & 119 \\
\hline Neutral detergent fibre & 180 & 592 & 853 & 593 & 503 & 432 \\
\hline D-value & & 708 & 439 & & $693 / 703$ & $711 / 645$ \\
\hline Lactic acid & & 34 & & & 21 & 27 \\
\hline Acetic acid & & 15 & & & 10 & 12 \\
\hline Butyric acid & & 3.9 & & & 0.5 & 2.6 \\
\hline Ethanol & & 5.5 & & & 4.7 & 6.9 \\
\hline Water-soluble carbohydrates & & 95 & & & 135 & 40 \\
\hline \multicolumn{7}{|l|}{ In total nitrogen, $\mathrm{g} \mathrm{kg}^{-1}$} \\
\hline Ammonia $\mathrm{N}$ & & 59 & & & 40 & 73 \\
\hline Soluble N & & 593 & & & 408 & 619 \\
\hline $\mathrm{pH}$ & & 4.12 & & & 4.18 & 4.03 \\
\hline \multicolumn{7}{|l|}{ Feed value, $\mathrm{kg}^{-1} \mathrm{DM}{ }^{1)}$} \\
\hline Metabolizable energy, MJ & 13.6 & 11.3 & 6.1 & 6.0 & $11.1 / 11.2$ & $11.0 / 10.0$ \\
\hline AAT, g & 105 & 82 & 54 & 49 & 83 / 84 & $86 / 80$ \\
\hline
\end{tabular}

D-value, digestible organic matter in dry matter

AAT, amino acids absorbed in the small intestine

1) Exp1; in vitro based, except metabolizable energy and AAT for barley and by-product. Exp2; in vitro / in vivo based. 
Manninen, M. et al. Effects of winter feeding strategies on the performance of suckler cows

treatments and sex was found for the BW of $\mathrm{Li} x$ AbAy calves and an interaction $(\mathrm{P}<0.05)$ between diet and sex for the BW of $\mathrm{Li} \times \mathrm{ChAy}$ calves. Afterwards treatments had no effect on calf daily
LWG averaging 1203, 1353 and $1301 \mathrm{~g}$ for pregrazing, grazing and pre-weaning for all the calves, respectively.

Table 2. Mean treatment effects on the in vivo apparent digestibility coefficients in Experiment 2.

\begin{tabular}{|c|c|c|c|c|c|c|c|c|}
\hline \multirow{2}{*}{$\begin{array}{l}\text { Diet (D) } \\
\text { Strategy (S) }\end{array}$} & \multicolumn{2}{|c|}{ Grass silage } & \multicolumn{2}{|c|}{ Whole-crop barley silage } & \multirow[b]{2}{*}{ SEM } & \multicolumn{3}{|c|}{ Significance $^{1)}$} \\
\hline & Step-up & Flat-rate & Step-up & Flat-rate & & $\mathrm{D}$ & $\mathrm{S}$ & $\mathrm{D} \times \mathrm{S}$ \\
\hline Number of groups & 2 & 2 & 2 & 2 & & & & \\
\hline \multicolumn{9}{|l|}{ Digestibility coefficients } \\
\hline Organic matter & 0.75 & 0.76 & 0.68 & 0.67 & 0.010 & $* *$ & & \\
\hline Neutral detergent fibre & 0.73 & 0.75 & 0.58 & 0.56 & 0.011 & $* * *$ & & \\
\hline Crude protein & 0.67 & 0.71 & 0.59 & 0.60 & 0.004 & $* * *$ & $* *$ & \\
\hline Starch & & & 0.94 & 0.93 & 0.010 & & & \\
\hline
\end{tabular}

SEM, Standard error of means

1) $* \mathrm{P}<0.05, * * \mathrm{P}<0.01, * * * \mathrm{P}<0.001$

Table 3. Mean daily intake of dry matter, crude protein, neutral detergent fibre, metabolizable energy and amino acids absorbed in the small intestine of cows during indoor feeding.

\begin{tabular}{|c|c|c|c|c|c|c|c|c|}
\hline \multirow{2}{*}{$\begin{array}{l}\text { Diet (D) } \\
\text { Strategy (S) }\end{array}$} & \multicolumn{2}{|c|}{ Control } & \multicolumn{2}{|c|}{ Alternative } & \multirow[b]{2}{*}{ SEM } & \multicolumn{3}{|c|}{ Significance $^{1)}$} \\
\hline & Step-up & Flat-rate & Step-up & Flat-rate & & $\mathrm{D}$ & $\mathrm{S}$ & $\mathrm{D} \times \mathrm{S}$ \\
\hline \multicolumn{9}{|l|}{ Number of groups } \\
\hline Exp1 & 2 & 2 & 2 & 2 & & & & \\
\hline Exp2 & 2 & 2 & 2 & 2 & & & & \\
\hline \multicolumn{9}{|l|}{ Dry matter intake, $\mathrm{kg}$} \\
\hline \multicolumn{9}{|l|}{ Exp1 } \\
\hline Grass silage & 5.58 & 5.58 & 2.79 & 2.79 & & & & \\
\hline Straw & 2.83 & 2.75 & & & & & & \\
\hline By-product & & & 5.30 & 5.30 & & & & \\
\hline Barley & 1.10 & 1.22 & 1.01 & 1.22 & & & & \\
\hline Mineral mixture & 0.08 & 0.05 & 0.10 & 0.06 & & & & \\
\hline Total & 9.59 & 9.60 & 9.20 & 9.38 & 0.105 & $*$ & & \\
\hline \multicolumn{9}{|l|}{ Exp2 } \\
\hline Grass silage & 8.83 & 8.82 & & & & & & \\
\hline Whole-crop silage & & & 8.76 & 8.74 & & & & \\
\hline Mineral mixture & 0.11 & 0.11 & 0.12 & 0.13 & & & & \\
\hline Total & 8.94 & 8.92 & 8.87 & 8.87 & 0.018 & $*$ & & \\
\hline \multicolumn{9}{|l|}{ Crude protein, $g$} \\
\hline Exp1 & 865 & 890 & 873 & 910 & 8.0 & & $*$ & \\
\hline Exp2 & 1248 & 1296 & 1032 & 1035 & 1.9 & $* * *$ & $* * *$ & $* * *$ \\
\hline \multicolumn{9}{|c|}{ Neutral detergent fibre, $g$} \\
\hline Exp1 & 5921 & 5872 & 4978 & 5017 & 72.1 & $* * *$ & & \\
\hline Exp2 & 4397 & 4424 & 3787 & 3776 & 6.8 & $* * *$ & & $*$ \\
\hline \multicolumn{9}{|c|}{ Metabolizable energy, MJ } \\
\hline Exp1 & 95.5 & 96.7 & 76.9 & 79.8 & 1.04 & $* * *$ & & \\
\hline Exp2 & $97.8 / 99.2$ & $97.7 / 99.1$ & 96.4 / 87.6 & $96.4 / 87.4$ & $0.17 / 0.16$ & $* * / * * *$ & & \\
\hline \multicolumn{9}{|c|}{ Amino acids absorbed in the small intestine, $\mathrm{g}$} \\
\hline Exp1 & 726 & 736 & 594 & 618 & 8.3 & $* * *$ & & \\
\hline Exp2 & $731 / 739$ & $734 / 742$ & $751 / 696$ & $751 / 696$ & $1.3 / 1.2$ & $* * * / * * *$ & & \\
\hline
\end{tabular}

Exp1, Experiment 1; Exp2, Experiment 2

SEM, Standard error of means

1) $* \mathrm{P}<0.05$, ** $\mathrm{P}<0.01, * * * \mathrm{P}<0.001$ 
Vol. 13 (2004): 348-362.

In Exp2, the average calf birth date was 26 March. An interaction $(\mathrm{P}<0.05)$ between the treatments and sex was found for BW. The treatments had no effect on calf daily LWG but pre-grazing, grazing and pre-weaning the males grew 167, 243 and $213 \mathrm{~g} \mathrm{~d}^{-1}$ better $(\mathrm{P}<0.05)$ than the females, respectively.

\section{Milk production, grazing and conception}

An interaction $(\mathrm{P}<0.05)$ between the treatments was found for the average milk production (Table 6). The average daily milk yield was greater for the cows fed Diet CF compared to those fed Diet CS, the opposite being true on Diets AF and AS. The

Table 4. Live weight, live weight gain, body condition score and change of body condition score of cows during indoor feeding and grazing.

\begin{tabular}{|c|c|c|c|c|c|c|c|c|}
\hline \multirow{2}{*}{$\begin{array}{l}\text { Diet (D) } \\
\text { Strategy (S) }\end{array}$} & \multicolumn{2}{|c|}{ Control } & \multicolumn{2}{|c|}{ Alternative } & \multirow{2}{*}{$\begin{array}{c}\text { SEM } \\
\text { min-max }\end{array}$} & \multicolumn{3}{|c|}{ Significance $^{1)}$} \\
\hline & Step-up & Flat-rate & Step-up & Flat-rate & & $\mathrm{D}$ & $\mathrm{S}$ & $\mathrm{D} \times \mathrm{S}$ \\
\hline $\mathrm{N}$ Exp1 & 13 & 14 & 13 & 14 & & & & \\
\hline Exp2 & 12 & 14 & 13 & 11 & & & & \\
\hline \multicolumn{9}{|c|}{ Live weight, $\mathrm{kg}$} \\
\hline \multicolumn{9}{|l|}{ Initial } \\
\hline Exp1 & 565 & 562 & 564 & 558 & $20.4-21.8$ & & & \\
\hline Exp2 & 707 & 692 & 683 & 696 & $7.5-8.8$ & & & \\
\hline \multicolumn{9}{|l|}{ Pre partum } \\
\hline Exp1 & 641 & 668 & 649 & 660 & $16.0-17.1$ & & & \\
\hline Exp2 & 778 & 779 & 739 & 775 & $14.8-17.4$ & & & \\
\hline \multicolumn{9}{|c|}{ End of experiment } \\
\hline Exp1 & 600 & 591 & 614 & 604 & $15.3-16.3$ & & & \\
\hline Exp2 & 764 & 764 & 748 & 762 & $13.9-16.3$ & & & \\
\hline \multicolumn{9}{|c|}{ Live weight gain, $\mathrm{kg}$} \\
\hline \multicolumn{9}{|c|}{ Start $\Rightarrow$ Grazing } \\
\hline Exp1 & -13 & -7 & -16 & -28 & $13.8-14.8$ & & & \\
\hline Exp2 & -22 & -12 & -8 & -8 & $6.3-7.4$ & & & \\
\hline \multicolumn{9}{|c|}{ Grazing $\Rightarrow$ End of experiment } \\
\hline Exp1 & 57 & 55 & 59 & 73 & $6.0-6.4$ & & & \\
\hline Exp2 & 79 & 83 & 73 & 74 & $7.2-8.5$ & & & \\
\hline \multicolumn{9}{|c|}{ Body condition score } \\
\hline \multicolumn{9}{|l|}{ Initial } \\
\hline Exp1 & 2.80 & 2.72 & 2.45 & 2.61 & $0.151-0.162$ & & & \\
\hline Exp2 & 3.42 & 3.43 & 3.16 & 3.35 & $0.093-0.109$ & & & \\
\hline \multicolumn{9}{|l|}{ Calving } \\
\hline Exp1 & 2.42 & 2.50 & 2.22 & 2.65 & $0.111-0.119$ & & & \\
\hline Exp2 & 2.96 & 3.17 & 2.89 & 2.96 & $0.093-0.109$ & & & \\
\hline \multicolumn{9}{|c|}{ End of Experiment } \\
\hline Exp1 & 2.53 & 2.42 & 2.40 & 2.53 & $0.169-0.180$ & & & \\
\hline Exp2 & 3.38 & 3.42 & 3.27 & 3.26 & $0.087-0.102$ & & & \\
\hline \multicolumn{9}{|c|}{ Change of body condition score } \\
\hline \multicolumn{9}{|c|}{ Start $\Rightarrow$ Grazing } \\
\hline Exp1 & -0.23 & -0.26 & -0.30 & -0.47 & $0.080-0.086$ & & & \\
\hline Exp2 & -0.24 & -0.19 & -0.15 & -0.21 & $0.042-0.049$ & & & \\
\hline \multicolumn{9}{|c|}{ Grazing $\Rightarrow$ End of experiment } \\
\hline Exp1 & -0.04 & -0.04 & 0.25 & 0.40 & $0.072-0.077$ & $* *$ & & \\
\hline Exp2 & 0.20 & 0.18 & 0.26 & 0.12 & $0.042-0.049$ & & & \\
\hline
\end{tabular}

Exp1, Experiment 1; Exp2, Experiment 2

SEM, Standard error of means

1) $* \mathrm{P}<0.05, * * \mathrm{P}<0.01, * * * \mathrm{P}<0.001$ 
Manninen, M. et al. Effects of winter feeding strategies on the performance of suckler cows

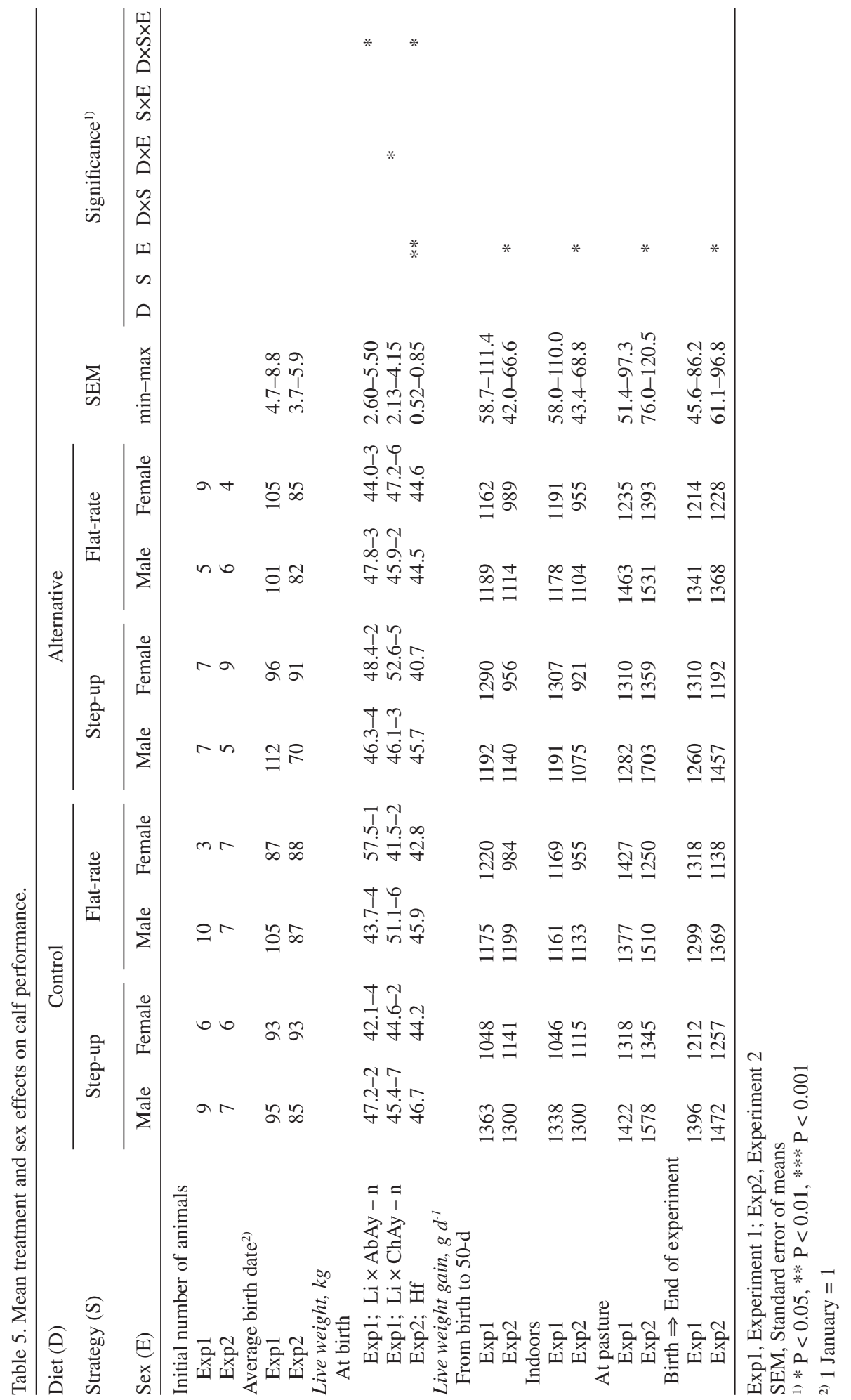


Vol. 13 (2004): 348-362.

average energy-corrected daily milk yield was $12.0 \mathrm{~kg}$ and the milk fat and the milk lactose content on average 40.1 and $49.1 \mathrm{~g} \mathrm{~kg}^{-1}$, respectively. Milk protein was $1.6 \mathrm{~g} \mathrm{~kg}^{-1}$ higher $(\mathrm{P}=0.09)$ on Strategy S than on Strategy F.

Pre-grazing herbage mass varied between 450 and $4700 \mathrm{~kg} \mathrm{DM} \mathrm{ha}^{-1}$ during the summer in Exp2. Mean post-grazing SH of the grazed area was 11 $\mathrm{cm}$ in both groups and the proportion of the infrequently grazed area was $22 \%$, although there was a large variation during the summer (0-68\%). Mean D value of the grass was $725, \mathrm{CP}$ content 218 and the ash content $86 \mathrm{~g} \mathrm{~kg}^{-1} \mathrm{DM}$. The pasture area for each cow-calf pair increased from 0.48 to 0.58 ha as the pasture growth decreased to the end of the grazing season.

In Exp1, one cow fed Diet CF was open after the mating period. In Exp2, 50 cows entered the mating period of which one on Diet AS was observed open. In Exp1 and Exp2, the duration from the calving to conception averaged 75 and 76 days, respectively and the calving intervals were 358 and 360 days.

\section{Discussion}

\section{Cow performance}

Straw and BP had the same ME content in Exp1. Since the proportion of BP on Diet A was higher than that of straw on Diet $\mathrm{C}$, the ME intake was clearly lower on Diet A. In Exp2, the energy content of GS was similar as evaluated by both in vitro and in vivo methods indicating the suitability of the in vitro method for the evaluation of the energy content of GS. In contrast, the in vitro method over-estimated the energy content of the WCBS by one MJ. This lead to lower ME intake with WCBS than GS since the ME value based on in vitro measurement was used when calculating the daily rations. The energy content of WCBS depends largely on the stage of maturity of the crop, the proportion of straw in the plant, the variety, the weather conditions and probably also the animal and the level of production (Kristensen 1992). In the present experiment, the digestibility of the

Table 6. Milk yield and milk composition in Experiment 1.

\begin{tabular}{|c|c|c|c|c|c|c|c|c|}
\hline \multirow{2}{*}{$\begin{array}{l}\text { Diet (D) } \\
\text { Strategy (S) }\end{array}$} & \multicolumn{2}{|c|}{ Control } & \multicolumn{2}{|c|}{ Alternative } & \multirow{2}{*}{$\begin{array}{c}\text { SEM } \\
\min -\max \end{array}$} & \multicolumn{3}{|c|}{ Significance $^{1)}$} \\
\hline & Step-up & Flat-rate & Step-up & Flat-rate & & $\mathrm{D}$ & $\mathrm{S}$ & $\mathrm{D} \times \mathrm{S}$ \\
\hline Number of animals & 6 & 6 & $6^{2)}$ & 6 & & & & \\
\hline \multicolumn{9}{|l|}{ Milk yield, $\mathrm{kg} \mathrm{d}^{-1}$} \\
\hline \multicolumn{9}{|l|}{ Day of lactation } \\
\hline 14 & 11.5 & 10.6 & 11.7 & 10.9 & $0.73-0.77$ & & & \\
\hline 28 & 10.5 & 11.8 & 12.7 & 10.3 & $0.62-0.66$ & & & $*$ \\
\hline 42 & 12.2 & 13.1 & 13.8 & 10.4 & $0.60-0.63$ & & & $*$ \\
\hline 56 & 11.6 & 12.5 & 13.7 & 11.0 & $0.84-0.88$ & & & \\
\hline 70 & 11.5 & 12.6 & 13.7 & 12.4 & $0.45-0.47$ & & & \\
\hline 84 & 12.9 & 13.6 & 13.4 & 12.4 & $0.46-0.49$ & & & \\
\hline 98 & 12.0 & 13.3 & 12.4 & 12.7 & $0.53-0.56$ & & & \\
\hline 112 & 11.4 & 12.7 & 12.7 & 13.0 & $0.50-0.53$ & & & \\
\hline Mean & 11.7 & 12.5 & 13.0 & 11.6 & $0.24-0.25$ & & & $*$ \\
\hline Mean, ECM & 11.7 & 11.9 & 12.7 & 11.8 & $0.44-0.47$ & & & \\
\hline \multicolumn{9}{|c|}{ Milk composition, $\mathrm{g} \mathrm{kg}^{-1}$} \\
\hline Fat & 41.3 & 38.2 & 40.0 & 42.8 & $2.23-2.36$ & & & \\
\hline Protein & 29.8 & 28.4 & 30.6 & 28.9 & $0.69-0.73$ & & & \\
\hline Lactose & 49.4 & 48.2 & 49.1 & 49.2 & $0.89-0.94$ & & & \\
\hline
\end{tabular}

SEM, Standard error of means

ECM, Energy-corrected milk

1) $* \mathrm{P}<0.05$, ** $\mathrm{P}<0.01$, *** $\mathrm{P}<0.001$

2) One cow lost her calf 8 July 
WCBS was considerably lower than that of the GS. However, the in vivo apparent digestibility coefficients of the WCBS for starch (0.932), CP (0.594) and $\mathrm{OM}(0.677)$ were in good accordance with the values of $0.959,0.598$ and 0.647 , measured with steers for whole-crop wheat silage harvested at the hard-dough stage of development (Deschard et al. 1988).

The whole-crop barley silage with a DM content of $335 \mathrm{~g} \mathrm{~kg}^{-1}$ was of moderate fermentation quality, as evidenced by a low $\mathrm{pH}$ and low ammonia but rather high butyric acid content. The WCBS proved to be suitable feed for the indoor feeding period in cold conditions because the high DM content conferred a non-freezing property.

The practical feeding occurred satisfactorily in both experiments with all feeds and strategies. Strategy $\mathrm{S}$ was uncomplicated to practice since the estimated calving dates were available due to pregnancy diagnosis. The duration of the indoor feeding period was on average seven months in Exp1. During this period the cows on Diets $\mathrm{C}$ and A received a total of 20400 and $16600 \mathrm{MJ}$ ME per cow, respectively. In Exp2 the experimental winter feeding period was six months, leading to total energy consumption on Diets C and A of 17600 and 15500 MJ ME, respectively. Broadbent (1984) advises a total of $12500 \mathrm{MJ}$ ME from 21 October to end of April during which the cows receive a constant level of 65 MJ ME per day. The amount of energy the cows received in the present study was, however, higher. Especially in Exp2 the BCS of the cows was probably too good for mature cows. In both experiments, there were no significant differences between the treatments in cow LW and LWG. At the onset of grazing in Exp1 the cows were on average $15 \mathrm{~kg}$ lighter but at the end of the experiment $41 \mathrm{~kg}$ heavier than at the beginning of the experiment. The average LWG from the start to the end of the experiment was quite similar and satisfactory in both experiments. The results suggest that a daily amount of $80 \mathrm{MJ}$ ME during the winter period offered with a flat-rate feeding strategy may be enough for beef cows in marginal circumstances. Implementation of this suggestion, however, requires knowledge of the energy content of the feeds available, knowledge of the size and BCS of the cows, as well as knowledge of the duration of the calving period and the post-calving lactating days indoors before grazing.

The treatments affected the BCS only in Exp1. At the beginning of Exp1, the cows were in moderate condition averaging 2.6 which may be slightly too low for crossbred cows after the grazing season (Lowman et al. 1976). This reflects both the good milk production capacity of the cows and probably the insufficient pasture area the cows had prior to the present experiment (Manninen and Taponen 2004). The BCS at calving indicates the minor effects of the feeding strategy on cow performance. At the onset of grazing cows fed Diet A had an average BCS of 2.1, which may, however, be acceptable (Lowman et al. 1976). At that time the lower BCS on Diet A compared to that achieved on Diet $\mathrm{C}$ is in good agreement with the amount of energy the cows received daily during the winter period, 78.4 vs. 96.1 MJ ME, respectively. On pasture, the change of BCS remained constant for the cows fed Diet C and the LWG was at least satisfactory. On Diet A, the animals improved their BCS.

In Exp2, the high post-grazing SH and the large proportion of infrequently grazed area in the middle of the grazing season indicated low pasture utilization. The recommended post-grazing $\mathrm{SH}$ for high production dairy cows in Finland is $9-10 \mathrm{~cm}$ and the proportion of infrequently grazed area less than $40 \%$ (Virkajärvi et al. 2002). Suckler cows in extensive production should manage well with a lower post-grazing SH and a smaller proportion of infrequently grazed area than dairy cows. In this case, the low pasture utilization caused a large amount of wasted grass and an increased need for topping. However, due to non-restricted feeding the cows condition score increased in the present experiment and was well above the recommendation in autumn (Lowman et al. 1976).

Vanzant and Cochran (1993) evaluated the impact of step-up protein supplementation strategies, using soybean meal/sorghum grain or dehydrated alfalfa pellets, on the performance of $\mathrm{Hf} \times$ Angus cows and their calves when grazing tallgrass prairie in winter. In agreement with the present study, the cows did not benefit appreciably from stagger- 
Vol. 13 (2004): 348-362.

ing the rate of feeding. The change in LW and BCS was affected somewhat by the immediate level of supplementation but had minor effects on reproductive performance or calf LWG.

The health of the cows was good in both experiments in spite of the three cows on Diet AF with premature delivery due to an infection by $B$. Licheniformis bacteria in Exp2. All three cows were in the same pen and probably the infection spread through the afterbirth.

The differences between treatments in the milk production and milk composition were small in Exp1. The suckling ability, in other words, the vigour of the calves, was good on the basis of the good calf LWG. Although the BCS was rather low on Diets CS and AS at calving and on Diets AS and $\mathrm{AF}$ at the onset of grazing, it did not seem to affect the milk production. This indicates the ability of the cows to mobilize body reserves for milk production.

The milk production was fairly constant during the entire experiment. A small increase in milk production was observed after day 28 of lactation, especially on Diets CF and AS, which may largely be due to the turnout to pasture. This observation is in good agreement with the well-known fact that the daily milk yield of beef cows increases slowly after calving and reaches a maximum 1-3 months post partum. On the other hand, the average milk production in the present study distinctly exceeded the commonly reported (e.g. Petit and Agabriel 1989) value of $1.0-1.2 \%$ of LW, mainly due to high milk production capacity of the beef-dairy crosses. The average milk production measured in this experiment is in good agreement with the results earlier reported by Manninen and Taponen (2004) with the same beef-dairy crosses and with the results of Manninen and Huhta (2001) for Hf $x$ Ay- and Li $\times$ Ay-cows, both milk production values being measured by the machine milking technique. In the present experiment the milk fat content was considerably lower than that observed by Manninen and Huhta (2001) and Manninen and Taponen (2004). Milk fat content agrees well with the values measured for Charolais by Petit and Agabriel (1989), but the protein content was lower. The milk lactose content is in good agreement with the results reported earlier (Manninen and Huhta 2001, Manninen and Taponen 2004).

In beef cow production, it is important to maintain the calving interval at about 365 days and the calving period at eight to ten weeks, at the same time of the year. In the present experiments this target was well achieved in all treatments. This indicates that the BCS was at least sufficient for rebreeding in Exp1 in spite of the low BSC values. However, the BCS of 2.3 for cows in Exp1 at the onset of grazing, is higher than the value of 1.5-2.0 suggested by Petit and Agabriel (1989) as adequate for cows calving in late winter (less than 60 days before turn-out) due to the high level of nutrition provided on good quality spring grass which induces a rapid return to heat and good fertility.

\section{Calf performance}

The effects of treatments on the calf LW and LWG were not significant. The relatively high BWs for both males and females did not cause calving problems. The primary reason for this finding is undoubtedly the age of the cows and the suitable BCS at calving. In addition, all calvings were monitored carefully which may also explain the low incidence of dystocial cases. The pre-weaning LWG was similar for calves on all treatments in both experiments although in Exp2 the males grew better than the females. The main reasons for the good LWG of the calves in both experiments arises from the good milk production capacity of the cows, although measured only in Exp1, and the good pastures available. The calf LWG measured in this experiment agree well with the earlier studies (Manninen et al. 1998, 2000, Manninen and Huhta 2001, Manninen and Taponen 2004), reflecting strongly the cow's ability to sustain milk production for the calf by using her own body reserves.

In conclusion, the flat-rate feeding strategy can be practised as a simple way of managing the nutrition of mature suckler cows during the long indoor period in marginal conditions. Flour-mill industry by-product with low energy content can replace straw and grass silage in the winter diet of 
the suckler cows. The effects of the WCBS on the cow performance were comparable to the good quality grass silage. Therefore, non-freezing WCBS with high DM content can be offered restricted as a sole feed for mature suckler cows in a cold environment. The cow BCS before the indoor feeding period must always be considered carefully when planning the winter diet and feeding strategy. A prerequisite for a successful winter feeding strategy is analysis of the energy content of each feed.

Acknowledgements. The authors wish to express their thanks to Mrs. Ulla Eronen and her staff for technical assistance during the experiments as well as Juha Hurmalainen, DVM, for his cooperation with the ultrasonic scanning programme. The evaluation of the manuscript by Dr. Seija Jaakkola is gratefully acknowledged. This work was financially supported by the Finnish Konkordia Fund. The flour-mill industry by-product used in Exp1 was received from Raisio Feed Ltd, which is gratefully acknowledged.

\section{References}

Alawa, J.P., Fishwick, G. \& Hemingway, R.G. 1988. Fresh and dried brewers' grains as protein supplements to barley straw diets given to pregnant beef cows. Animal Feed Science and Technology 19: 33-41.

Alawa, J.P., Fishwick, G., Parkins, J.J. \& Hemingway, R.G. 1987. A note on the effects of dietary protein degradability in the rumen on the voluntary intake and digestibility of barley straw by lactating beef cows. Animal Production 44: 446-449.

Alawa, J.P., Fishwick, G., Parkins, J.J., Hemingway, R.G. \& Aitchison, T.C. 1986. Influence of energy source and dietary protein degradability on the voluntary intake and digestibility of barley straw by pregnant beef cows. Animal Production 43: 201-209.

Andries, J.I., de Brabander, D.L. \& Buysse, F.X. 1988. Feeding strategies for dairy cattle. Comparison of flat rate feeding and standard feeding during early lactation. Archives of Animal Nutrition 38: 651-661.

AOAC 1990. Official methods of analysis. 15th ed. AOAC International, Arlington, USA. Vol. 1, sec. 984.13.

Beck, T.J., Simms, D.D., Cochran, R.C., Brandt, R.T., Jr., Vanzant, E.S. \& Kuhl, G.L. 1992. Supplementation of ammoniated wheat straw: Performance and forage utilization characteristics in beef cattle receiving energy and protein supplements. Journal of Animal Science 70: 349-357.

Broadbent, P. 1984. Suckler cow feeding strategies. North of Scotland College of Agriculture. Digest No. 7. 11 p.
Deschard, G., Mason, V.C. \& Tetlow, R.M. 1988. Treatment of whole-crop cereals with alkali. 4. Voluntary intake and growth in steers given wheat ensiled with sodium hydroxide, urea or ammonia. Animal Feed Science and Technology 19: 55-66.

Fike, G.D., Simms, D.D., Cochran, R.C., Vanzant, E.S., Kuhl, G.L. \& Brandt, R.T., Jr. 1995. Protein supplementation of ammoniated wheat straw: Effect on performance and forage utilization of beef cattle. Journal of Animal Science 73: 1595-1601.

Friedel, K. 1990. Die Schätzung des energetischen Futterwertes von Grobfutter mit Hilfe einer Cellulasemethode. [The estimation of the energetic feeding value of roughages by means of a cellulase method]. Wissenschaftliche Zeitschrift Universitet Rostock, N-Reihe 39: 78-86.

Haacker, K., Block, H.J. \& Weissbach, F. 1983. Zur kolorimetrischen Milchsäurebestimmung in Silagen mit pHydroxydiphenyl. [On the colorimetric determination of lactic acid in silages with p-hydroxydiphenyl]. Archiv für Tierernährung 33: 505-512.

Hameleers, A. 1998. The effects of the inclusion of either maize silage, fermented whole crop wheat or ureatreated whole crop wheat in a diet based on a highquality grass silage on the performance of dairy cows. Grass and Forage Science 53: 157-163.

Huhtanen, P.J., Blauwiekel, R. \& Saastamoinen, I. 1998. Effects of intraruminal infusions of propionate and butyrate with two different protein supplements on milk production and blood metabolites in dairy cows receiving grass silage based diet. Journal of the Science of Food and Agriculture 77: 213-222.

Huida, L. 1973. Quantitative determination of volatile fatty acids from rumen sample and silage by gas-liquid chromatography. Journal of the Scientific Agricultural Society in Finland 45: 483-488.

Huida, L., Väätäinen, H. \& Lampila, M. 1986. Comparison of dry matter contents in grass silages as determined by oven drying and gas chromatographic water analysis. Annales Agriculturae Fenniae 25: 215-230.

Komprda, T. \& Dolezal, P. 1996. Crude protein degradability, protein digestible in the intestine and net energy for lactation of whole crop barley on various vegetative stages. Archives of Animal Nutrition 49: 325-333.

Kristensen, V.F. 1992. The production and feeding of whole-crop cereals and legumes in Denmark. In: Stark, B.A. \& Wilkinson, J.M. (eds.). Whole-crop cereals. Chalcombe Publications. p. 21-37.

Lippke, H., Ellis, W.C. \& Jacobs, B.F. 1986. Recovery of indigestible fiber from feces of sheep and cattle on forage diets. Journal of Dairy Science 69: 403-412.

Lowman, B.G., Scott, N.A. \& Somerville, S.H. 1976. Condition scoring of cattle. The East of Scotland College of Agriculture. Animal Production, Advisory and Development Department. Bulletin No. 6. 31 p.

McCleary, B.V., Solah, V. \& Gibson, T.S. 1994. Quantitative measurement of total starch in cereal flours and products. Journal of Cereal Science 20: 51-58.

McCullough, H. 1967. The determination of ammonia in whole blood by direct colorimetric method. Clinica Chimica Acta 17: 297-304.

MAFF 1975. Energy allowances and feeding systems for 
Vol. 13 (2004): 348-362.

ruminants. Technical Bulletin 33. Ministry of Agriculture, Fisheries and Food. Her Majesty's Stationery Office, London. $79 \mathrm{p}$.

MAFF 1984. Energy allowances and feeding systems for ruminants. ADAS Reference Book 433. Ministry of Agriculture, Fisheries and Food. Her Majesty's Stationery Office, London. $85 \mathrm{p}$.

Mann, M.E., Cohen, R.D.H., Kernan, J.A., Nicholson, H.H., Christensen, D.A. \& Smart, M.E. 1988. The feeding value of ammoniated flax straw, wheat straw and wheat chaff for beef cattle. Animal Feed Science and Technology 21: 57-66.

Manninen, M., Aronen, I. \& Huhta, H. 2000. Effect of feeding level and diet type on the performance of crossbred suckler cows and their calves. Agricultural and Food Science in Finland 9: 3-16.

Manninen, M., Aronen, I., Puntila, M.-L., Heikkilä, R. \& Jaakkola, S. 1998. Effect of type of forage offered and breed on performance of crossbred suckler heifers and their calves. Agricultural and Food Science in Finland 7: 367-380.

Manninen, M. \& Huhta, H. 2001. Influence of pre partum and post partum plane of nutrition on the performance of crossbred suckler cows and their progeny. Agricultural and Food Science in Finland 10: 3-18.

Manninen, M. \& Taponen, J. 2004. Influence of feeding accuracy on the performance of Aberdeen Angus $\times$ Ayrshire and Charolais $\times$ Ayrshire crossbred suckler cows and their progeny. Livestock Production Science 85: 65-79.

Moloney, A.P. \& O'Kiely, P. 1997. Digestibility, nitrogen retention and plasma metabolite concentrations in steers offered whole-crop wheat silage-based rations. Irish Journal of Agricultural and Food Research 36: 135144.

O'Kiely, P. \& Moloney, A.P. 1995. Performance of cattle offered whole-crop barley or wheat silage. Irish Journal of Agricultural and Food Research 34: 13-24.

Petit, M. \& Agabriel, J. 1989. Beef cows. In: Jarrige, R. (ed.). Ruminant nutrition. Recommended allowances and feed tables. INRA, Paris. p. 93-108.

Poole, D.A. 1987. Flat $v$. step feeding of medium or high levels of concentrates for dairy cows. Animal Production 45: 335-344.

Salo, M.-L., Tuori, M. \& Kiiskinen, T. 1982. Rehutaulukot ja ruokintanormit. (Feed tables and feeding recommendations). Helsinki. $70 \mathrm{p}$.

SAS 1999. SAS/STAT user's guide. Version 8, Cary, NC. SAS Institute Inc. 3809 p.

Somogyi, M. 1945. A new reagent for the determination of sugars. Journal of Biological Chemistry 160: 61-68.

Sutton, J.D., Phipps, R.H., Cammell, S.B. \& Humphries, D.J. 2001. Attempts to improve the utilization of ureatreated whole-crop wheat by lactating dairy cows. Animal Science 73: 137-147.

Tuori, M., Kaustell, K., Valaja, J., Aimonen, E., Saarisalo, E. \& Huhtanen, P. 1996. Rehutaulukot ja ruokintasuositukset (Feed tables and feeding recommendations). 2nd ed. Yliopistopaino, Helsinki. 99 p.

Tuori, M., Kaustell, K., Valaja, J., Aimonen, E., Saarisalo, E. \& Huhtanen, P. 2000. Rehutaulukot ja ruokintasuositukset (Feed tables and feeding recommendations). 3rd ed. Yliopistopaino, Helsinki. 88 p.

Van Soest, P.J., Robertson, J.B. \& Lewis, B.A. 1991. Methods for dietary fiber, neutral detergent fiber and nonstarch polysaccharides in relation to animal nutrition. Journal of Dairy Science 74: 3583-3597.

Vanzant, E.S. \& Cochran, R.C. 1993. Step-up protein supplementation for beef cows grazing dormant, tallgrass prairie. Journal of Production Agriculture 6: 236-240.

Varhegyi, J., Varhegyi, J. \& Borbely, I. 2000. Possibilities for utilization of agricultural by-products by beef herds. A/lattenyesztes es takarmanyozas 49: 510-518.

Virkajärvi, P., Sairanen, A., Nousiainen, J.I. \& Khalili, H. 2002. Effect of herbage allowance on pasture utilization, regrowth and milk yield of dairy cows in early, mid and late season. Animal Feed Science and Technology 97: $23-40$. 


\title{
SELOSTUS
}

\section{Tasaruokinnan ja vaihtoehtoisten rehujen soveltuvuus emolehmien talvikauden ruokintaan}

\author{
Merja Manninen, Kirsi Saarijärvi, Harri Huhta, Lauri Jauhiainen ja Pentti Aspila \\ MTT (Maa- ja elintarviketalouden tutkimuskeskus)
}

Osassa Suomea ei ole riittävästi olkea emolehmien talviruokintaan. Kokoviljasäilörehu on puolestaan osoittautunut varteenotettavaksi rehuksi emolehmien talvikauden ruokintaan. Kokoviljasäilörehulla ruokittaessa ruokinnan suunnittelua vaikeuttaa kuitenkin se, että rehun energiapitoisuudelle ei ole täysin luotettavaa määritysmenetelmää.

Pitkän astutuskauden vuoksi poikimiset ajoittuvat emolehmätiloilla monesti usean kuukauden ajalle. Sisäruokintakauden eläimet ovat ryhmissä, jolloin lisäruokinta on hankalaa kohdentaa yksilöllisesti. Tasaisella ruokinnalla eläimen saama energiamäärä on yhtä suuri kuin porrastetulla (ylläpito-tunnutus-herutus) ruokinnalla, mutta energiamäärä jakaantuu tasaisesti koko sisäruokintakauden ajalle. Tasainen ruokinta perustuu siihen, että eläin varastoi ennen poikimista ylimääräisen energian kudosrasvoiksi, joita se sitten hyödyntää mm. maidontuotantoon ennen laidunkautta.

Tämän tutkimuksen tavoitteena oli selvittää oljen ja säilörehun osittainen korvattavuus kaurankuoripohjaisella teollisuuden sivutuotteella (Koe 1) sekä ohrakokoviljasäilörehun soveltuvuus ja tuotantovaikutukset (Koe 2) emolehmillä kylmissä tuotanto-olosuhteissa. Molempia ruokintavaihtoehtoja tarkasteltiin tasaisella ja porrastetulla ruokinnalla.

Kokeessa 1 oli 56 risteytysemoa, jotka kokeen alussa painoivat keskimäärin $567 \mathrm{~kg}$, ja Kokeessa 2 oli 56 herefordemoa, jotka kokeen alussa painoivat keskimäärin $692 \mathrm{~kg}$. Koemalli oli $2 \times 2$ faktoriaalinen. Faktoreina ruokintastrategia (porrastettu vs. tasainen) ja rehutyyppi (kontrolli vs. vaihtoehtoinen). Kokeessa 1 kontrolliruokinnalla nurmisäilörehun osuus oli 0,55 ja oljen 0,45 kuiva-aineen syönnistä, vaihtoehtoisella ruokinnalla nur- misäilörehun ja teollisuuden sivutuotteen osuudet olivat vastaavasti 0,3 ja 0,7 . Ruokinta porrastettiin ohralla, jota annettiin $60 \mathrm{~d}$ ennen poikimista 1,5 ja poikimisen jälkeen $3,5 \mathrm{~kg} / \mathrm{d}$. Tasaisella ruokinnalla eläimet saivat ohraa koko sisäruokintakauden ajan 1,43 kg/d. Kokeessa 2 eläimet saivat joko nurmisäilörehua tai ohrakokoviljasäilörehua tasaruokintana $97 \mathrm{MJ} \mathrm{ME} / \mathrm{d}$ tai porrastetusti 68-95-119 MJ ME/d.

Kokeen 1 emot saivat kontrolli- ja vaihtoehtoruokinnoilla keskimäärin 96,1 ja 78,3 ja Kokeen 2 emot vastaavasti 99,2 ja 87,5 MJ ME/d. Ruokintojen välillä ei esiintynyt eroja emojen elopainossa kummassakaan kokeessa. Kokeen 1 porrastetulla ruokinnalla olleet emot olivat poikiessa hieman heikommassa kunnossa kuin tasaisella ruokinnalla olleet emot. Laidunkaudella Kokeen 1 vaihtoehtoisella ruokinnalla olleet emot kuntoutuivat puolestaan hieman kontrolliruokinnalla olleita emoja paremmin. Kokeessa 2 ruokintojen välillä ei kuntoluokissa esiintynyt eroja. Kokeen 1 emojen energiakorjattu maidontuotanto oli keskimäärin 12,0 kg päivässä. Kokeen 1 vasikat kasvoivat keskimäärin $1301 \mathrm{~g} / \mathrm{d}$. Kokeen 2 sonnivasikat kasvoivat lehmävasikoita paremmin. Ajanjakso poikimisesta uudelleen tiinehtymiseen kesti 75 päivää Kokeessa 1 ja 76 päivää Kokeessa 2.

Tulosten perusteella tasaruokintaa voidaan suositella täysikasvuisille emolehmille kylmiin tuotanto-olosuhteisiin. Mikäli saatavilla on hinnaltaan kilpailukykyistä teollisuuden sivutuotetta, sillä voidaan korvata olkea ja säilörehua talvikauden rehustuksessa. Kokoviljasäilörehu soveltuu hyvin hyväkuntoisille emolehmille talvikauden ainoaksi rehuksi mm. jäätymättömyytensä ansiosta. 